\title{
指先の摩擦モデルに関する研究*
}

\author{
鈴 木 健 $太^{* 1}$, 渡 邊 鉄 也*2, 田中 基八郎*3
}

\section{Study on Finger Tip Model with Friction}

\author{
Kenta SUZUKI, Tetsuya WATANABE*4 and Kihachiro TANAKA
}

${ }^{* 4}$ Division of Mechanical Engineering and Science, Saitama University,
255 Shimo-Okubo, Sakura-ku, Saitama-shi, Saitama, 338-8570 Japan

\begin{abstract}
Generally a coefficient of friction of a human finger is very higher than a coefficient of friction of metal. The physical characteristics of a human finger are important in the work by hand. Therefore, the physical and numerical modeling of fingertip is useful for the design of various equipments, for example, a handrail of stairs, a robot hand, an operation simulator, and so on. In this study, "Coulomb friction", "absorption by fingerprint and sweat" and "elasticity of finger" are considered as the element of the friction characteristics. The aim of this study is to express the force by these characteristics as function model and to make the physical fingertip model. At first, the force by friction and absorption are measured, and the contact area between fingertip and board is calculated. Next, the function of friction force with respect to vertical force acting on the contact surface between fingertip and board is suggested. Finally, the actual finger model is made and the friction force is modeled to the function.
\end{abstract}

Key Words: Skin, Finger Tip, Friction, Contact Area, Modeling of Fingertip

\section{1. 緒言}

人間の生活において, 摩擦は切り離して考えること のできないものである. 皮膚の摩擦により姿勢を保ち, 手作業を行うことなどが可能となっている. そして, 人間の皮膚の中でも手指は最も効率の良い摩擦を発揮 する. 手指の働きは，掴む，摘むの 2 種類に分けられ るが，そのうち摘むという行為においては，指先の摩 擦特性が影響するものであり, 人間が行う高度な手作 業を可能にしているといえる.

一般に，人間の手の摩擦係数は 1.3 以上とされてお り，条件においてはさらに大きい数值を示すことが明

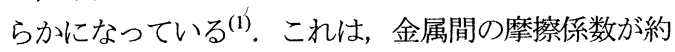
0.3 であることと比較すると, 非常に大きい. ゆえに, 指先の摩擦特性を解明し応用することができれば, 手 すりに代表される住環境の改善やロボットハンドなど の機械による手作業の効率向上, 手術シミュレータの

$*$ 原稿受付 2007 年 12 月 27 日.

*1 埼玉大学大学院理工学研究科(恋338-8570さいたま市桜区 下大久保 255).

*2 正員, 埼玉大学大学院理工学研究科.

*3 正員, フェロー, 埼玉大学大学院理工学研究科.

E-mail : watanabe@mech.saitama-u.ac.jp
精度向上，また，自動車や化粧品など人間が触れるも のの商品性向上にもつながる.

現在, 摩擦係数が大きくなる理由として, 指先の柔 らかさによる弾性, 指紋形状, 発汗作用による湿潤な どが要因であると考えられている(2).これまで，指先 の摩擦に関する物理的特性をモデル化した研究は行わ れているが(3)-(5)，指紋や発汗による影響までを考慮し たものではない.

そこで, 本研究では, 指先の摩擦がクーロン摩擦力, 指紋と発汗による吸着力, 弾性力の 3 要素で構成され ていると考え，それぞれの特性について検討した．ま ず, 指先の摩擦にはクーロン摩擦以外の要素が作用し ていることを確認した. 次に, 指紋と発汗により発生 する吸着力を測定した. 吸着力は垂直抗力に対して非 常に小さいことから, 摩擦力の増加には影響しないこ とがわかった. 次に, 指先の弾性について検討し, 指 先の弾性が摩擦力の增加へ大きく関わっていることが わかった. これらの結果から, 指先の摩擦力と垂直抗 力の関係を関数として数式で示した. また, 模擬指を 製作し，その摩擦特性を実験的に調查し，その結果か ら摩擦力を垂直抗力の関数で示すことができた. 


\section{2. 実指の摩擦力}

$2 \cdot 1$ 摩摖力測定装置 図 1 は実験装置の概略図 である. 図 2 は実写真と指先を摩擦する方向である. この摩擦力測定装置は, モ一タの回転をタイヤを介し てx 軸アルミクロスローラステージ(NBK, TAM-100s) のマイクロメータ部に伝える. ステージ部分に高さを 調節することができる台を設置し，その上に 3 分力計

（共和電業, LSM-B-SA1）を設置する. 3 分力計には 指を乗せる治具が設置されており，マイクロメータが 回転することでステージが左右に移動し, 固定したア クリル板と治具上の指の間で摩擦が生じる仕組みにな っている.このとき生じる治具への反力をそれぞれ摩 擦力, 垂直抗力として 3 分力計を用いて測定する. デ 一タは3 分力計の信号がアンプ(共和電業, DPM-613B) で増幅され，センサインターフェイス（共和電業, PCD-300A,320A）を通じて PC に保存されるようにな っている. なお，手の自重は実験装置に取り付けたバ ンドによって支えるようになっている.
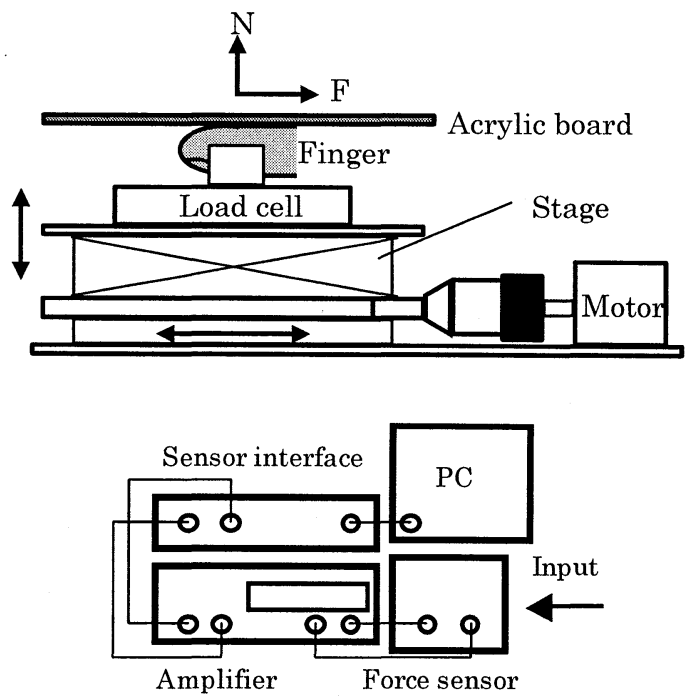

Fig.1 Experimental apparatus

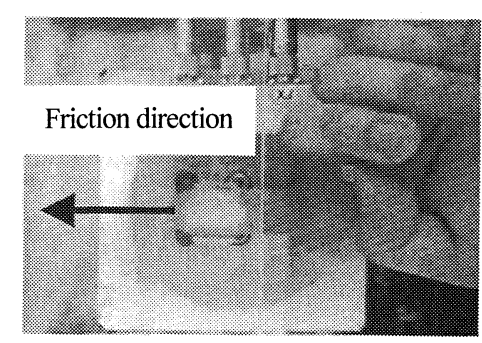

Fig.2 Measurement of friction
$2 \cdot 2$ 実指の摩擦特性 実指を用いて, 指先の最 大静止摩擦力 $F$ を, 垂直抗力 $N$ を変化させながら測定 した. また, 汗が指先の摩擦力を増加させる一因とな っていることから，指先をエタノールで脱脂した直後 と脱脂 20 分後の 2 パターンで図 2 に示した方向の摩擦 力測定を行い, 汗が摩擦力へ与える影響の比較を行っ た.

図 3 は摩擦力の時刻歷波形である. 摩擦始めから約 10 秒を過ぎたところで最大静止摩擦力に達し, その後, 動摩擦へ切り替わることがわかる．次に，指に生じる 摩擦現象をクーロン摩擦と仮定した上で, 式(1)から摩 擦係数を求めた.

$$
\begin{array}{ll}
F=\mu N & \\
F & \text { : 最大静止摩擦 [N] } \\
N & \text { : 垂直抗力 }[\mathrm{N}] \\
\mu & \text { : 摩擦係数 }
\end{array}
$$

図 4 に垂直抗力に対する摩擦係数の変化を示寸. 摩 擦係数は垂直抗力が増加寸るにつれて 0.5 付近の値に 収束していった.この結果から, 指先の摩擦にはクー ロン摩擦以外の力が作用していることがわかる. 図 5 に示した垂直抗力に対する摩擦力の変化から, 脱脂直 後は垂直抗力が大きくなると傾きが一定になっていく ことがわかる. 脱脂 20 分後は脱脂直後に比べてばらつ きが大きくなっている. これは, 脱脂後 20 分という放 置時間が長すぎるため，発汗量が過剩になり，すべり が生じやすくなってしまったためだと考えられる.

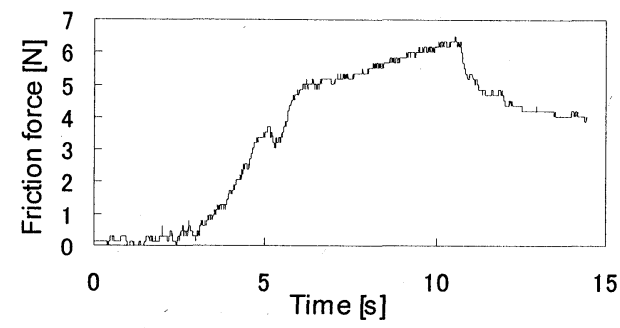

Fig.3 Friction force

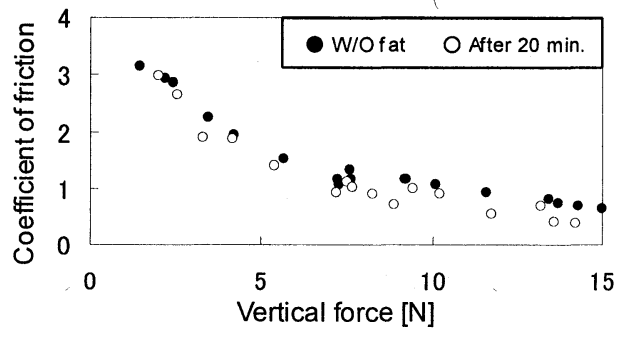

Fig.4 Coefficient of friction 
$2 \cdot 3$ 指先の吸着力 人間の指先は指紋を有して おり，発汗作用と指紋形状によって吸盤効果を生じる といわれている．本節では，指の摩擦特性に吸着力が 関連していると考え, 吸着力を測定する実験を行った. 図 6 に実験装置の一部を示す．この実験では，前節で 使用した摩擦力測定装置を用いる. まず，両端固定の アクリル板が荷重によって生じる歪を歪ゲージで測定 し, 荷重に対する歪の傾き $\alpha$ を求めておく. 次に指先 でアクリル板を荷重し, その時の最大荷重を測定する. そこから指先を戻し，アクリル板から剥がれたときに 生じる歪に, 求めておいた $\alpha$ をかけることで吸着力を 算出する．指をアクリルに押し付けたときの最大荷重 を変化させて測定を行い, 最大荷重の大きさによる吸 着力の変化を調べた.

図 7 は荷重と歪の関係を表した図である.この図か ら, 傾き $\alpha$ は 0.0029 となった. 図 8 は歪ゲージの時刻 歴波形で, 図中のAが，指がアクリルから剥がれる時 である。

図 9 は最大荷重に対する吸着力を求めたものである. それぞれ，○が脱脂直後，○が脱脂 5 分後， 口が水を つけた場合の吸着力である. 脱脂直後と脱脂 5 分後の 結果を見ると, 垂直抗力の増加にともない吸着力が増 加することがわかる. また, 脱脂 5 分後の方が吸着力 は大きくなった. 水をつけた場合は垂直抗力が増加し ても吸着力は小さかった。この結果から，指先には吸 着力が発生し, 適度な湿りが吸着力を増加させること がわかった. しかし, 吸着力は垂直抗力が $20 \mathrm{~N}$ に対し て最大でも $0.45 \mathrm{~N}$ 程度しかないため, 摩擦力増加への 影響は少ないと考えられる.

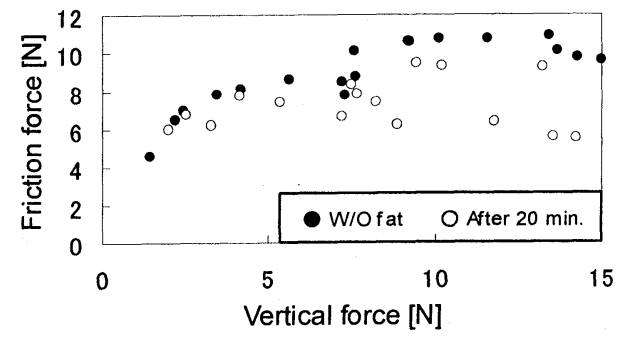

Fig.5 Friction force

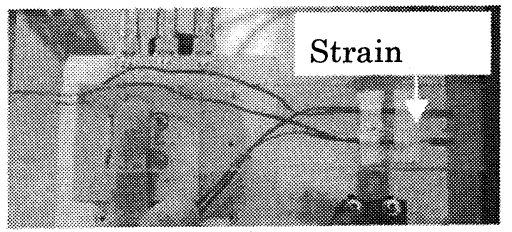

Fig.6 Measurement of absorption force
2・4 指先の弾性および接触面積 指先の弾性が摩 擦力を増加させる一要因であると考えられる.ここで は，アクリルに押し付けた時の指先とアクリルとの接 触面積を測定し，摩擦力との関連を検討する.

実験は図 1 の摩擦力測定装置を用いる，まず，朱肉 を塗った指先をアクリル板に押し付け，そのときの垂 直抗力を測定する.アクリル板に写った楕円状の朱肉 の跡から指先の接触面積を測定する.

ヘルツの接触理論より ${ }^{(6)}$, 弾性体を剛体または弾性 体で圧縮する際，任意の曲面と曲面の接触に関して式 (2)が成り立つ. 添字 1 は指, 添字 2 はアクリル板を示 す.この式から，接触面積は物体の弾性係数の関数で 表すことができる ${ }^{(7),(8)}$ ，そこで，レーザ一変位センサ

（KEYENCE LB-60）を用いてアクリル板に指を押し 付けた際の指先の変位から, 指先のヤング率を測定し た. 図 10 に垂直抗力に対するヤング率を示す. 指先の ヤング率は垂直抗力により増加していることがわかる. これは指先の中の骨や爪による影響と考えられる.

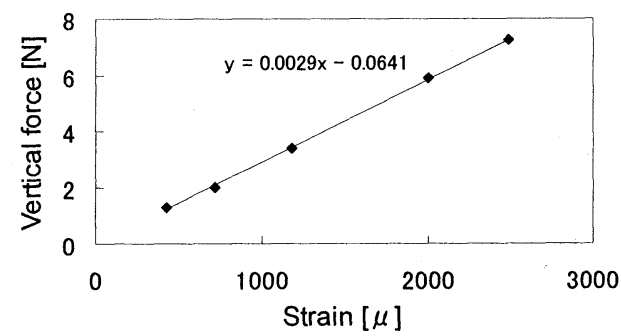

Fig.7 Vertical force with respect to strain

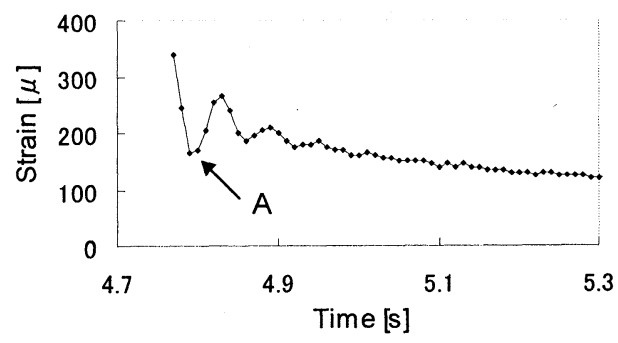

Fig.8 Strain time history

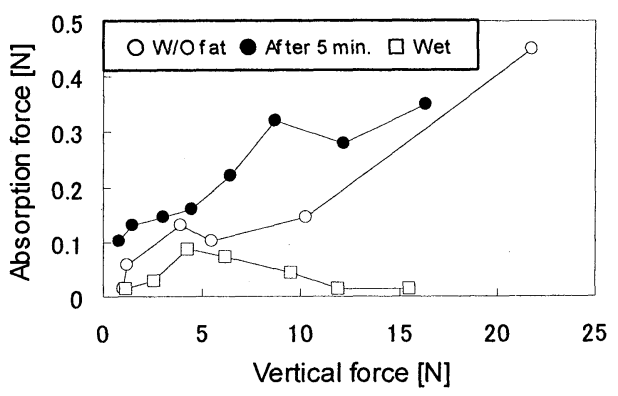

Fig.9 Absorption force 


$$
\begin{aligned}
a=\left(\frac{3}{4} P\left(\frac{1-v_{1}^{2}}{E_{1}}+\frac{1-v_{2}^{2}}{E_{2}}\right) /\left(\frac{1}{R_{1}}+\frac{1}{R_{2}}\right)\right)^{\frac{1}{3}} \\
P \quad: \text { 圧縮荷重 }[\mathrm{N}] \\
E \quad: \text { ヤング率 }\left[\mathrm{N} / \mathrm{mm}^{2}\right] \\
v \quad: \text { ポアソン比 } \\
a \quad: \text { 接触円半径 }[\mathrm{mm}] \\
R \quad: \text { 曲率半径 }[\mathrm{mm}]
\end{aligned}
$$

図 11 に垂直抗力に対する接触面積の変化を示す.垂 直抗力が大きくなると一定の值に収束していく傾向を 示している. また, 図 5 の垂直抗力に対する摩擦力が 一定の傾きに収束していくことから，垂直抗力に対す る接触面積の増加傾向之摩擦力の増加傾向が類似して いることがわかる. 図 11 に式(2)と図 10 から得られた 曲線を示す，この曲線の傾向は実験結果と比較的良好 に一致しており, 摩擦力の増加は指先の弾性による接 触面積に影響されることがわかる.

$2 \cdot 5$ 指先の摩擦モデル 以上の結果から, 指先 の摩擦力のモデル化を行う. 図 12 は脱脂直後の実指先 の摩擦力である. 垂直抗力が大きくなると傾きが一定 になっていくことがわかる. 垂直抗力が大きくなると 接触面積の変化が少なくなるため，この傾きはクーロ ン摩擦の係数 $\mu$ であると考えられる. まず, 近似曲線

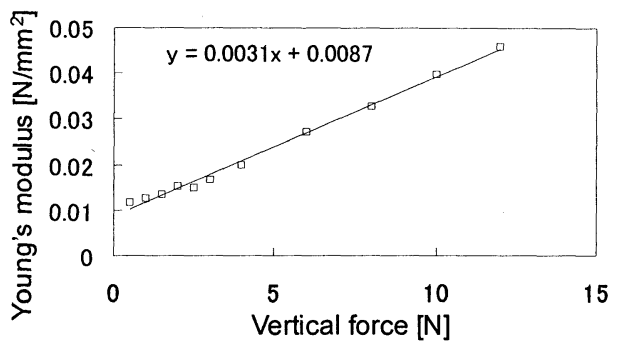

Fig.10 Young's modulus

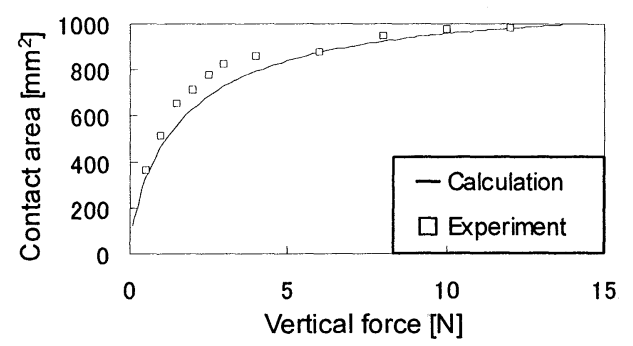

Fig.11 Contact area

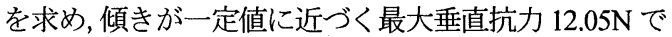
の接線から傾き $\mu$ を求める. その接線を原点に移動し たものが，指が固体摩擦であると仮定した時のクーロ ン摩擦になり，その線からの増加分が弾性変形による ものと考えた.この接線の傾き $\mu$ は 0.17 となった.

求めた $\mu$ を用いて, 図 12 の摩擦力功 $\mu N$ を引いた ものが弾性のみの影響による摩擦力の増加分というこ とになる. 図 13 は垂直抗力に対し, 縦軸を摩擦力から $\mu N$ を引いた值である. このグラフを近似したものが 弾性のみの影響による摩擦力の増加分で,

$$
F=1.8 \ln (N)+4.0
$$
となった。

以上から, クーロン摩擦の項と弾性による摩擦力の 増加分を足し合わせたものが指先の摩擦モデルとなり， 式(4)のように表すことができる.

$$
F=0.17 N+1.8 \ln (N)+4.0
$$

式(4)から，摩擦力を計算して実験值と比較する. 図 14 は垂直抗力に対する摩擦力の実験值と計算值であ る. 計算値は実験值と良く一致していることがわかる。

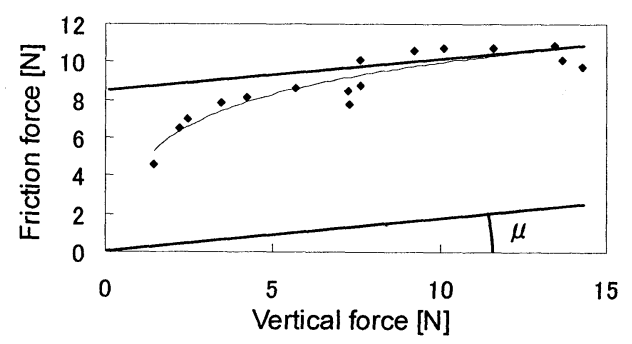

Fig.12 Friction force

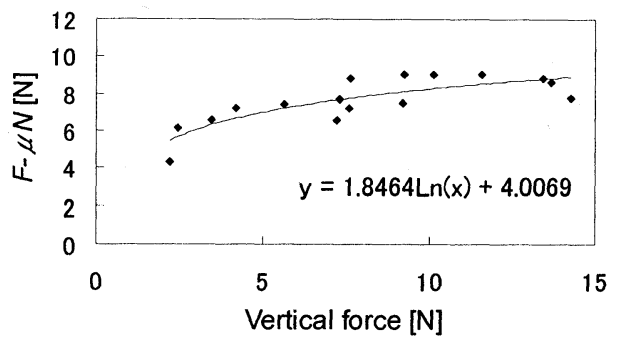

Fig.13 Force by elasticity

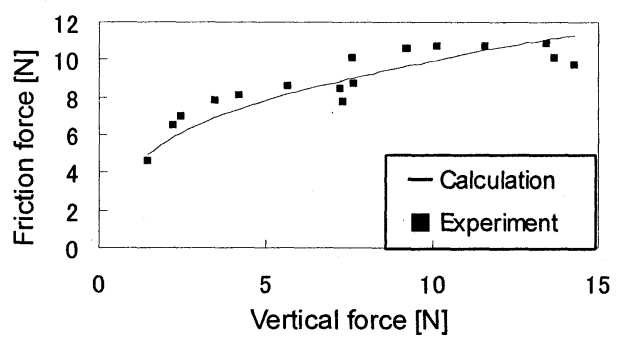

Fig.14 Friction force 


\section{3. 模擬指の摩擦力}

$3 \cdot 1$ 模擬指の製作 指の硬さ，骨の形状などに よる摩擦特性の違いを調べるため, 簡易的に模擬指を 製作した，骨は木材を削りだして製作した，信越シリ コーン(KE17)で指先の型をとり，その型に超軟質ウレ タン樹脂（エクシールコーポレーション，硬度 5,15) を流し込んで模擬指を製作した。爪隹は，つけ爪を接着 した. 図 15 に製作した模擬指の写真と寸法を示寸.

$3 \cdot 2$ 模擬指の摩摖特性 製作した模擬指で摩擦 力を測定した. 実験装置は図 1 の摩擦力測定装置を使 用し，硬度 5,15 それぞれの摩擦力を測定した. 図 16 はクーロン摩擦と仮定した場合の垂直抗力に対寸る摩 擦係数で, 図 17 が垂直抗力に対する摩擦力である. そ れぞれ○が硬度 5 の模擬指, 一が硬度 15 の模擬指であ る. 硬度 5,15 ともに垂直抗力が大きくなるにつれて 摩擦力が一定の傾きに収束し, 実指の傾向と同様にな った. また, 硬度 15 の方が硬度 5 より摩擦力が若干大 きくなることがわかった.

$3 \cdot 3$ 模擬指の吸着力 $2 \cdot 3$ 節と同様の実験装置, 実験方法で模擬指の吸着力を測定した. 図 18 に最大荷 重に対する吸着力を示す，○，口は硬度が5 の場合の 表面乾燥状態および表面湿潤状態を示す。また，

曰は硬度が 15 の場合の表面乾燥状態および表面湿潤 状態を示寸.表面湿潤状態とは水をつけた状態である. これらの図から, 表面乾燥状態では吸着力は最大荷重 とともに增加し, 表面湿潤状態では吸着力が小さいこ とがわかる. また, 乾燥状態でも最大 $0.4 \mathrm{~N}$ 程度の力し か発生せず，摩擦力の増加にはほぼ影響しないと考え られる.これは, 図9の実指の吸着力と類似する結果 となった.
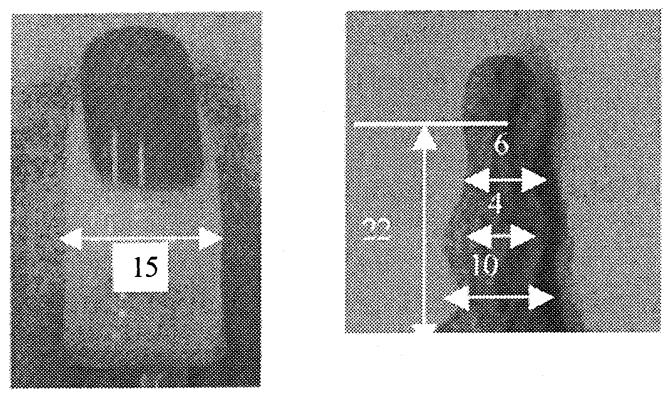

Fig.15 Dummy finger (Unit: mm)
$3 \cdot 4$ 模擬指先の弾性および接触面積 $2 \cdot 4$ 節と 同様の実験方法を用いて, アクリル板に写った朱肉の 跡から模擬指の接触面積を測定した. 図 19 は垂直抗力 に対する接触面積である. ○が硬度 5 , ○が硬度 15 の 結果で, どちらも一定の值に収束し, 実指と同様な傾 向を示した. また, 硬度が小さい方が柔らかく変形し やすいため，接触面積も大きくなることがわかる.

これらの結果から, 摩擦特性, 吸着力, 弾性におい て模擬指は実指を良く模擬できている.

$3 \cdot 5$ 模擬指先の摩擦力モデル $2 \cdot 5$ 節之同様な 考え方で模擬指の摩擦モデルを導いた. 図 20, 図 21 にそれぞれ硬度 5,15 の摩擦力を示す. 図中の四表面 乾燥状態の摩擦力の実験值で, 曲線は計算値である. 両図とも計算值と実験值は良好に一致していることが わかる. また, 指先の硬さが摩擦力の大きさに影響し, 硬度 15 の方が摩擦力は若干大きくなることがわかっ た. 得られた摩擦力モデルの式は, 硬度 5 が,

$$
F=0.21 N+1.7 \ln (N)+2.6
$$
硬度 15 が,

$$
F=0.25 N+2.1 \ln (N)+2.7
$$
である.

硬度が 15 の場合, 図 14 と傾向が似ていることから, 模擬指は実指の摩擦力を良く模擬できている.

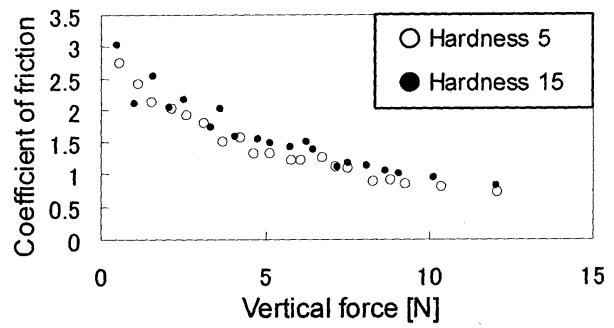

Fig. 16 Coefficient of friction

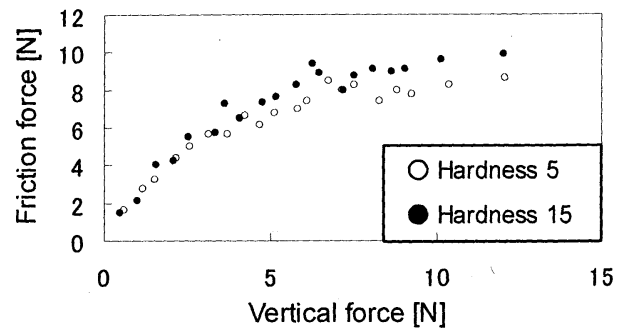

Fig.17 Friction force 


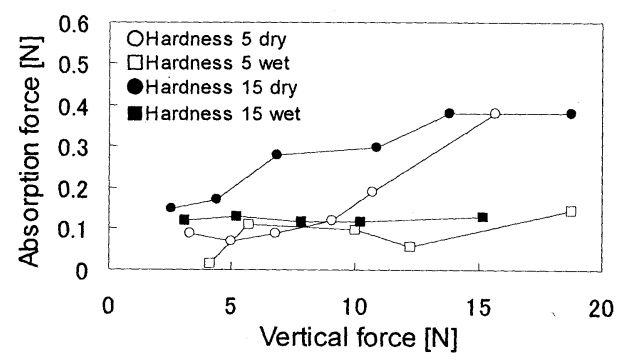

Fig.18 Absorption force

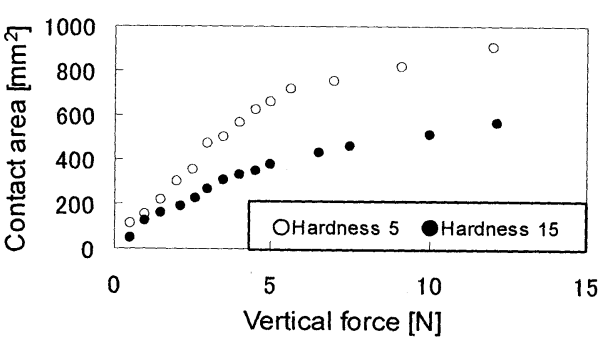

Fig.19 Contact area

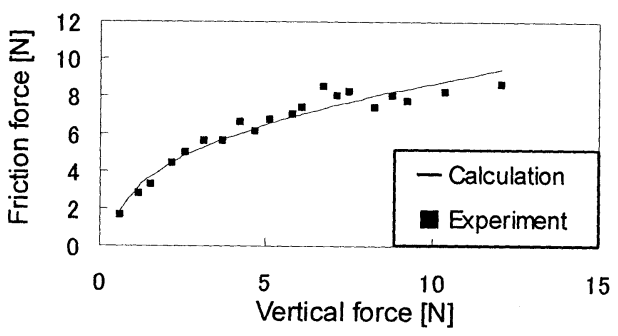

Fig.20 Friction force (Hardness 5)

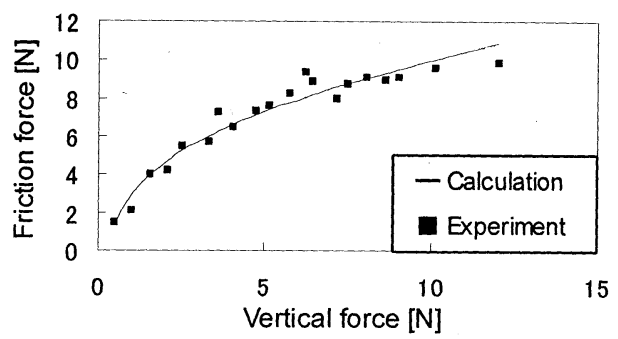

Fig.21 Friction force (Hardness 15)

\section{4. 結 言}

本研究では，指先の摩擦特性について実指，模擬指 の実験的解析を行い，表面状態，指先の柔らかさの違 いによる摩擦特性を比較し，摩擦モデルを作成するこ とを目的とした. 本研究で得られた結果を以下に示す.

(1)クーロン摩擦を仮定して得られた摩擦係数は，指先 の状態 (発汗, 乾燥) に関わらず，垂直抗力に対し て減少する傾向を示し，指先の摩擦にはクーロン摩 擦以外の力が作用している。

(2)吸着力は垂直抗力の大きさに対して無視できる程 度の值である.

(3)指先とアクリル板との接触面積の増加傾向が摩擦 力の増加傾向と類似していることから，摩擦力の増 加は指先の弾性による影響が大きい.

(4)指先の摩擦はクーロン摩擦と弾性の和で表せると 考えて摩擦モデルを構築した。

(5)模擬指を製作し，摩擦特性を測定したところ，実指 と同様の傾向を示した.

(6)模擬指の摩擦モデルを構築した.

\section{参考文献}

(1) Sasada,T., Ide,E., Kawakami,T., Friction Behavior of Human Skin (First Report), Report of C.I.T. No.45(1998), pp.13-19.

(2) Sasada,T., Kurihara,E., Friction Behavior of Human Skin (Second Report), Report of C.I.T. No.45(1998), pp.21-28.

(3) Yamaha,K., Takano,H., Ozaki,S., Physical characteristics of finger (Friction and elasticity, material ), Biomechanism, 3(1975), pp.27-36.

(4) Shimada,A., Han,H., Kawamura,S., Analysis of Friction Characteristics on Human Fingers, Transactions of SICE, 32-12(1996), pp.1033-1044.

(5) Tada,M., Shibata,T., Imai,M., Ogasawara,T., Development of the simultaneous measurement system of finger tip deformation and grip / load force for studies of human grasping skill, Journal of institute of electronics, information, and communication engineers, Vol.J84-D-II,6(2001), pp.1033-1044.

(6) Nakahara,I., Strength of Materials, Yokendo (1965)

(7) Maeno,T., Kobayashi,K., Yamazaki,N., Relationship between Structure of Finger Tissue and Location of Tactile Receptors, Journal of JSME C, 63-607(1997), pp.881-888.

(8) Yoshiaki,I., Fujita,K., Display of Soft Elastic Object by Simultaneous Control of Fingertip Contact Area and Reaction Force, Transactions of the Virtual Reality Society of Japan, 9-2(2004), pp.1-8. 